\title{
EFFECTS OF LIGHT ILLUMINATION AND SUBCULTURE FREQUENCY ON BIOMASS PRODUCTION IN CELL SUSPENSION CULTURES OF Clinacanthus nutans
}

\author{
FUI JOO BONG, SREERAMANAN SUBRAMANIAM and BEE LYNN CHEW* \\ School of Biological Sciences, Universiti Sains Malaysia, 11800 Penang, Malaysia \\ *E-mail: beelynnchew@usm.my
}

Accepted 7 June 2021, Published online 30 June 2021

\begin{abstract}
Clinacanthus nutans (Burm. f.) Lindau is a medicinal plant rich in polyphenols and possesses multiple pharmacological properties. It is widely used as a side treatment for cancer and to prevent oxidative stress-related diseases. The present study aims to investigate the effects of light illumination and subculture frequency on the growth and proliferation of cells in the suspension culture of $C$. nutans. Friable callus induced from leaf explants $C$. nutans were cultured in liquid Murashige \& Skoog medium supplemented with $0.25 \mathrm{mg} / \mathrm{L} \mathrm{2,} \mathrm{4-dichlorophenoxyacetic} \mathrm{acid,} \mathrm{and} 0.25 \mathrm{mg} / \mathrm{L}$ 6-benzylaminopurine to initiate the cell suspension culture. The suspension cultures were incubated under different conditions (16 hr photoperiod and continuous darkness). Subcultures were conducted every two weeks for ten subculture cycles. Results revealed that higher cell biomass was obtained under the exposure of $16 \mathrm{hr}$ photoperiod with the highest biomass production at the fifth subculture cycle (growth index of 11.8) exhibiting stable growth from the eighth to the tenth subculture cycle. The suspension cells showed stable growth rates up to the $10^{\text {th }}$ subculture cycle producing small aggregates and single cells. The present study indicated that light illumination significantly impacts the growth of suspension cultures for $C$. nutans in the production of valuable secondary metabolites.
\end{abstract}

Key words: Callus, cell suspension culture, Clinacanthus nutans, light, subculture frequency

\section{INTRODUCTION}

Clinacanthus nutans (Burm. f.) Lindau, locally known as Sabah Snake Grass or Belalai Gajah is a popular medicinal plant in Southeast Asia. It is traditionally used to treat insect bites, snake bites, and viral infections. The plant gained popularity in Asia due to its potential anti-cancer properties. The leaves of this plant have been widely used as complementary and alternative medicine (CAM) to delay cancer progression or to prevent cancer by the infusion of dried leaves in water or consumed as tea (Fong et al., 2019). The utilization of CAM has been shown to enhance health and physical well-being, wound healing, and reduce the side effects from chemotherapy among cancer patients (Dhanoa et al., 2014). Numerous studies have also reported on the anti-cancer properties of $C$. nutans particularly on its anti-proliferative activity against human cancer cell lines such as breast, liver, colon, and cervical which further suggested that this herbal plant can be

* To whom correspondence should be addressed. potentially used as a complementary approach to treat and prevent cancer (Yong et al., 2013; Arullappan et al., 2014; Hamid \& Yahaya, 2016; Wang et al., 2019). Besides, the plant is also known to possess significant pharmacological properties such as antioxidant (Khoo et al., 2015; Sarega et al., 2016), anti-viral (Kunsorn et al., 2013), anti-inflammatory (Mai et al., 2016), and antiangiogenic activities (Ng et al., 2018).

Previous studies revealed the presence of phenolics, flavonoids, alkaloids, steroids, phytosterols, saponins, diterpenes, proteins, and polysaccharides in the leaves and stem extracts C. nutans, further contributing to its pharmacological activities (Mustapa et al., 2015; Rahim et al., 2016; Kong et al., 2019). However, the production of bioactive compounds in $C$. nutans has been reported to not only be affected by external environmental factors such as climate, altitude, and soil conditions (Kong \& Abdullah Sani, 2017) but also postharvesting factors such as storage duration and conditions (Raya et al., 2015). This results in the inconsistent accumulation and harvest of bioactive 
compounds particularly for the production of valuable secondary metabolites.

Plant cell culture approaches have been successfully established as an alternative method for the production of valuable secondary metabolites for pharmaceutical purposes and as food additives under controlled conditions without the interference of seasonal, environmental variations, and geographical restrictions (Yue et al., 2016; Cardoso et al., 2019). Cell suspension culture, on the other hand, has been reported to be potentially beneficial in the large-scale production of novel secondary metabolites due to its rapid growth and short biosynthetic cycles (Tan et al., 2010). The production of valuable secondary metabolites from cell suspension cultures has been successfully reported in many plants such as the accumulation of paclitaxel from Taxus baccata (Tabata, 2004), camptothecin from Camptotheca acuminate (Pi et al., 2010), and shikonin from Arnebia euchroma (Hao et al., 2014).

Several strategies have been used to enhance the production of cell biomass and secondary metabolites. This includes the selection of highyielding cell cultures and the manipulation of chemical or physical factors to improve the growth of cell biomass and to stimulate the biosynthesis of secondary metabolites (Murthy et al., 2014). The accumulation of cell biomass via the in vitro system has been reported to be influenced by various factors such as plant growth regulators, light, and temperature (Bordbar et al., 2015; Georgieva et al., 2015). Light illumination is one of the key factors in cell cultures particularly to provide energy for the metabolism of the cultured cells. However, the conditions in the maintenance of cell cultures are species-specific. Besides, repetitive subculture practice is a critical step in maintaining cultures and stimulating continuous growth. Phua et al. (2018) and Bong et al. (2021) have reported on the successful establishment of cell suspension culture in C. nutans for the production of phenolics and flavonoids. However, both studies did not include reports on the effects of light exposure duration and subculture frequency on the growth of cell cultures of $C$. nutans. Hence, the current study aims to evaluate the effects of light illumination and subculture frequency contributing to efficient biomass production in the cell suspension culture of $C$. nutans, enabling the further establishment of highly productive cell culture of C. nutans.

\section{MATERIALS AND METHODS}

\section{Callus culture}

The callus of $C$. nutans was initiated by culturing leaf explants on MS (Murashige and Skoog, 1962) medium supplemented with $0.25 \mathrm{mg} / \mathrm{L} 2,4-\mathrm{D}$ and 0.25 $\mathrm{mg} / \mathrm{L}$ BAP, $30 \mathrm{~g} / \mathrm{L}$ sucrose, and $2.75 \mathrm{~g} / \mathrm{L}$ Gelrite ${ }^{\mathrm{TM}}$ (Duchefa, Netherlands) as described by Bong et al. (2021). The $\mathrm{pH}$ of the medium was adjusted to $5.7 \pm$ 0.1 before autoclaving at $121^{\circ} \mathrm{C}$ for 15 min under the pressure of $1.05 \mathrm{~kg} \mathrm{~cm}^{-2}$ (Tomy ES-315, Japan). All cultures were maintained in the culture room at $25 \pm$ $2{ }^{\circ} \mathrm{C}$ under $16 \mathrm{hr}$ photoperiod provided by cool white fluorescent lamps (Philips TL-D, 36W). The callus cultures were subcultured at four-week intervals for callus proliferation.

\section{Effect of light on cell biomass production}

An initial inoculum of $0.5 \mathrm{~g}$ of friable callus was dispensed into $150 \mathrm{~mL}$ Erlenmeyer flasks containing $25 \mathrm{~mL}$ of liquid MS medium supplemented with 0.25 $\mathrm{mg} / \mathrm{L} 2,4-\mathrm{D}$, and $0.25 \mathrm{mg} / \mathrm{L}$ BAP. All the cultures were maintained at $25 \pm 2{ }^{\circ} \mathrm{C}$ on an orbital shaker with constant agitation of 120 r.p.m under different conditions which are $16 \mathrm{hr}$ photoperiod with cool white fluorescent lamps and $24 \mathrm{hr}$ continuous darkness with six replicates for each treatment. For the treatment in darkness, the cultures were covered with aluminum foil and placed in conditions similar to the other cultures exposed to light. The cells were harvested on the $14^{\text {th }}$ day using suction-filtering through filter paper in a porcelain funnel connected to the vacuum pump and the fresh weight of the cells was weighed. The dried weight was obtained by oven drying the fresh cells at $40^{\circ} \mathrm{C}$ until a constant weight was attained. The collected data were analyzed via an independent t-test at $p<0.05$ (SPSS version 24).

\section{Effect of subculture frequency on cell biomass production}

The suspension cells were harvested and subcultured into $25 \mathrm{~mL}$ fresh medium with the same media composition every two weeks to study the effect of subculture frequency on cell biomass production. A total of $0.5 \mathrm{~g}$ of suspension cells were used as the initial mass with six replicates for 10 consecutive subculture cycles. All the cultures were maintained at $25 \pm 2{ }^{\circ} \mathrm{C}$ on an orbital shaker with constant agitation of 120 r.p.m under $16 \mathrm{hr}$ photoperiod under cool white fluorescent lamps. The cells were separated from the liquid media by suction-filtering through filter paper in a porcelain funnel connected to a vacuum pump after 14 days of each subculture. The fresh weight and growth index were determined at the end of each subculture cycle. Data were analyzed using one-way analysis of variance (ANOVA) followed by mean comparison using Duncan's Multiple Range Test (DMRT) at $p \leq 0.05$ (SPSS version 24).

\section{Experimental design and statistical analysis}

All experiments were set up as a completely randomized design and all data was analyzed using IBM SPSS version 24. 


\section{RESULTS AND DISCUSSION}

\section{Effect of light illumination on cell biomass production}

In the current study, light illumination resulted in a positive response in terms of the production of cell biomass in the cell suspension culture of $C$. nutans (Table 1). Results revealed that there was a significant difference in the fresh weight and dry weight of the cell biomass produced from the light and dark treatments. The cell biomass (fresh and dry) measured was significantly higher in the cultures exposed to $16 \mathrm{hr}$ photoperiod compared to the cells cultured under complete darkness. A total of $0.771 \mathrm{~g}$ fresh weight and $0.050 \mathrm{~g}$ dry weight were produced from the cultures incubated in the $16 \mathrm{hr}$ photoperiod whereas the cultures placed under complete darkness produced $0.616 \mathrm{~g}$ of fresh weight and $0.043 \mathrm{~g}$ of dry cell weight. The fresh and dry cell biomass obtained under the treatment of 16-hr photoperiod was 1.25 fold and 1.16-fold, respectively and these values were higher than the cell biomass obtained under complete darkness. Cell cultures incubated under the $16 \mathrm{hr}$ photoperiod changed from pale yellow to whitish (Figure 1A and 1B) whereas the cultures grown under dark conditions changed from pale yellow to light brown (Figure 1C and 1D).

Light illumination is an important exogenous factor for plant growth and development. It provides an energy source to build the fundamental blocks for plant growth (Ali \& Abbasi, 2014). It also has significant effects on plant morphogenesis and biochemical pathways particularly in the biosynthesis of primary and secondary metabolites (Mir et al., 2017). Light influences the rate of cell division, chloroplast differentiation, and photosynthetic pathway stimulation in plants (Garcia et al., 2011). Besides, light is needed for photo-morphogenesis and chlorophyll biosynthesis in plant tissue culture (George, 2008). In addition, light functions as an abiotic elicitor for the induction of specific enzyme activities involved in the accumulation of secondary metabolites in plant cells (Murthy et al., 2014).

In the present study, cell cultures exposed to light was found to produce higher cell biomass than cell cultures incubated under the dark condition. This indicated that light illumination is crucial for cell growth and proliferation in $C$. nutans. According to Rikiishi et al. (2008), light signaling stimulates the physiological changes in tissue cultures such as the level of endogenous hormones in plant cells. Light modulates the auxin signaling system and controls the level of auxin in plant tissue for plant growth and development (Halliday et al., 2009). Previous reports also indicated that light is essential for the growth of suspension cultures of Artemisia absinthium (Ali \& Abbasi, 2014). They found that light-grown cultures exhibited 3.9-folds higher in terms of dry biomass in comparison to the dry biomass obtained from the dark-grown cultures. Jalil et al. (2015) also observed that the cell cultures of Zingiber zerumbet incubated under 16:8 (light:dark) condition doubled in the initial biomass production compared to the cultures incubated under the dark condition.

In contrast, several studies have shown that cell cultures grown in dark displayed a higher cell growth rate than cell cultures that were exposed to light (Wu et al., 2007; Beigmohammadi et al., 2019). Mir et al. (2017) observed that the dark-grown cultures of Artemisia amygdalina produced higher dry biomass within the log phase when compared to light-grown cultures. Hasanloo et al. (2008) also noted that the growth of cells and flavonolignan accumulation in the suspension culture of Silybum marianum was higher in the dark-grown cultures than in the light-grown cultures. They explained that this could be due to light exposure influencing the lower expression rate of key enzymes for the biosynthesis of gibberellins, resulting in lower growth rates in the cultures. Besides, illumination had also no significant effect on the growth and cell biomass accumulation on cell suspension cultures in Angelica sinensis (Zhang et al., 2019) and Orthosiphon stamineus (Bordbar et al., 2015). This was not the case for the cells of $C$. nutans as the light was observed to be an important factor for cell growth in liquid media.

\section{Effect of subculture frequency on cell biomass production}

The effect of subculture frequency on cell biomass production in suspension culture of $C$. nutans cultured in MS liquid medium supplemented with $0.25 \mathrm{mg} / \mathrm{L} 2,4-\mathrm{D}$, and $0.25 \mathrm{mg} / \mathrm{L}$ BAP for ten

Table 1. Effect of light on fresh weight, dry weight, and growth index of cell suspension culture

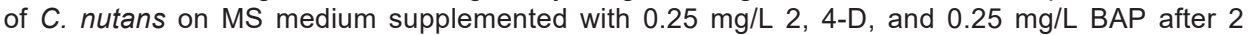
weeks of culture

\begin{tabular}{lccc}
\hline Illumination & Fresh weight $(\mathrm{g})$ & Dry weight $(\mathrm{g})$ & Growth index \\
\hline 16-hr photoperiod & $0.771 \pm 0.014^{\mathrm{a}}$ & $0.050 \pm 0.001^{\mathrm{a}}$ & $0.541 \pm 0.029^{\mathrm{a}}$ \\
24-hr continuous darkness & $0.616 \pm 0.016^{\mathrm{b}}$ & $0.043 \pm 0.001^{\mathrm{b}}$ & $0.232 \pm 0.033^{\mathrm{b}}$ \\
\hline
\end{tabular}

Results are expressed as mean \pm standard error of six replicates. Values followed by the same letter are not significantly different (Independent samples t-test at $p<0.05$ ). 

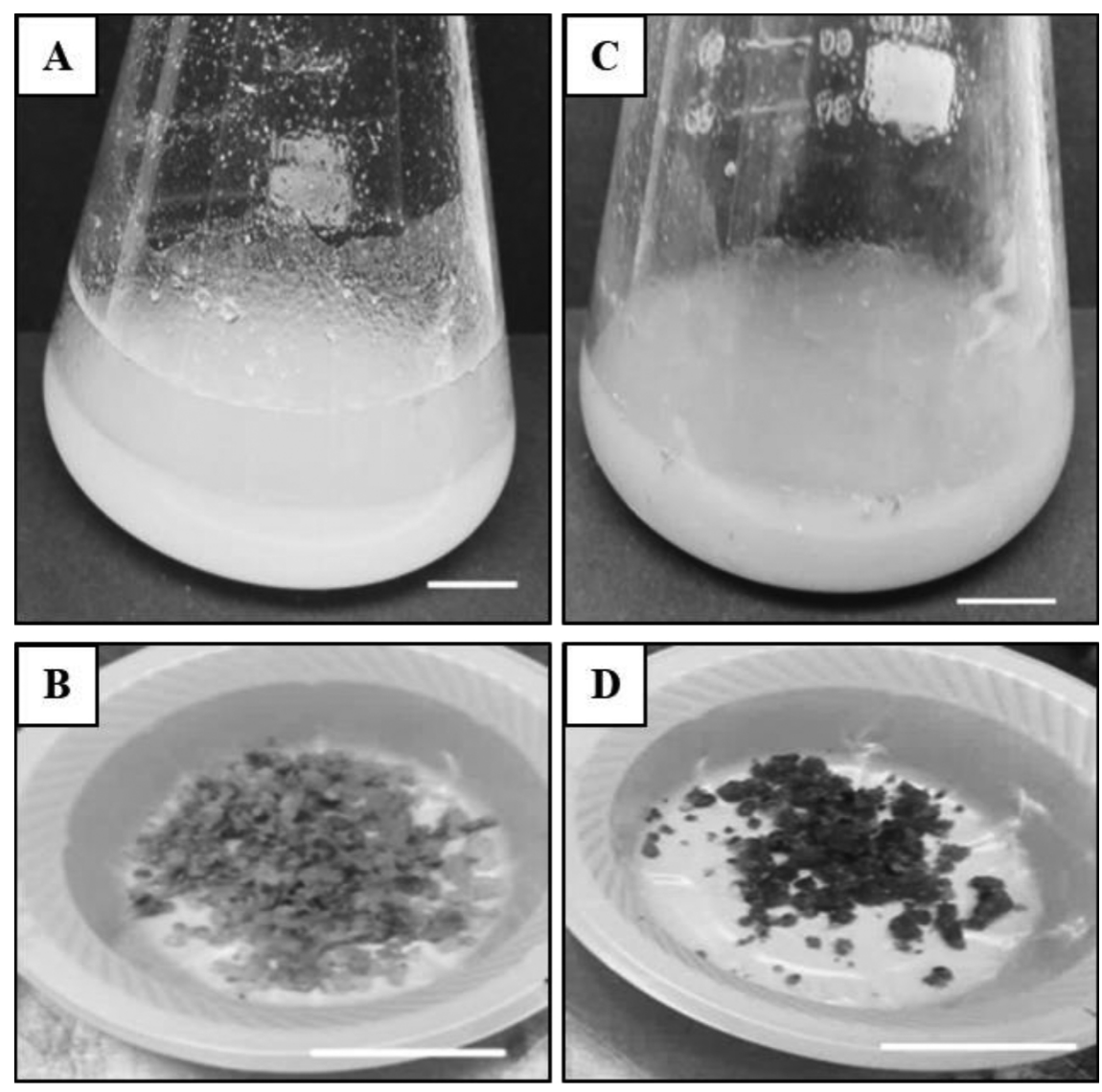

Fig. 1. Effect of light on physical characteristics of cell suspension culture of C. nutans after 2 weeks of culture. (A, B) light and (C, D) darkness. Scale bars represent $1 \mathrm{~cm}$.

subculture cycles is presented in Figure 2. The growth index recorded ranging from 0.33 to 11.80 . Over ten subculture cycles, the growth of the cells showed a progressively increasing trend from the first subculture to the fifth subculture cycle. The lowest growth index was recorded at the first subculture cycle with a growth index of 0.33 and fresh cell weight of $0.665 \mathrm{~g}$. There was a sharp increase in the growth index from the third to the fifth subculture. The highest growth index (11.80) was achieved at the fifth subculture cycle and a total of $6.211 \mathrm{~g}$ of fresh weight of cells was obtained, which was significantly higher than other subculture cycles. The growth index was 35.73 times higher than the initial growth index. After the fifth subculture cycle, the growth index declined until the ninth subculture cycle, from 5.94 down to 1.87. The growth index of cells then slightly increased at the tenth subculture cycle with the value of 2.32. There was no significant difference observed between the eighth and the tenth subculture cycle in terms of cell fresh weight. This indicated that the cells showed a constant and stable growth pattern from the eighth to the tenth subculture with the fresh weight of cells ranging from $1.436 \mathrm{~g}$ to $1.660 \mathrm{~g}$. Throughout the ten subculture cycles, the color of the cultures changed from pale yellow to white at the third subculture cycle and this remained unchanged until the tenth subculture cycle (Figure 3 ). The cell cultures were morphologically homogenous comprising of a mixture of small cell aggregates and fine cells.

Subculture of cell suspension is important to maintain ensure and maintain the healthy condition of cells for a prolonged duration. This step has to be carried out before the cultures enter the stationary phase (Wahyuni et al., 2020). During the stationary phase of the cultures, several growth-limiting factors can inhibit cell growth such as exhaustion of nutrients in the culture medium, oxygen depletion, and the accumulation of toxic by-products, metabolites, or dead cells (Neumann et al., 2009). Cultures need to be subcultured into the new medium to maintain the viability of the cells. In this study, the cell suspension culture of $C$. nutans was successfully established using a friable callus. A previous study conducted by Ch'ng and Chan (2013), showed that the growth of cell suspension culture was significantly affected by the texture of callus. They revealed that the cell suspension culture of Artemisia annua developed from friable callus showed fast-growing, stable, and sustainable characteristics as well as being homogenous, which 


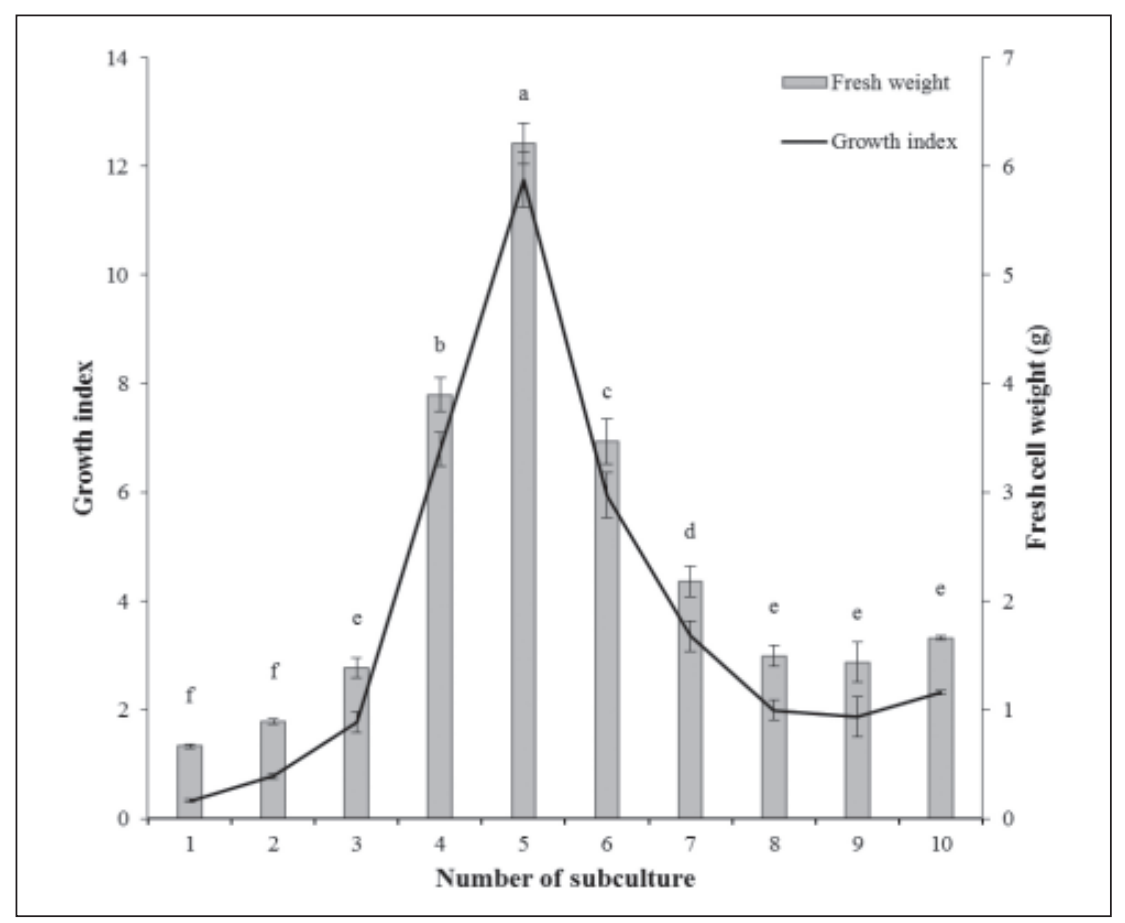

Fig. 2. Effect of subculture frequency on growth index and fresh cell weight of cell suspension cultures of $C$. nutans for ten subculture cycles. Results are expressed as mean \pm standard error (error bar) of six replicates. Values followed by the same letter are not significantly different (Duncan's multiple range test at $\mathrm{p} \leq 0.05$ ).
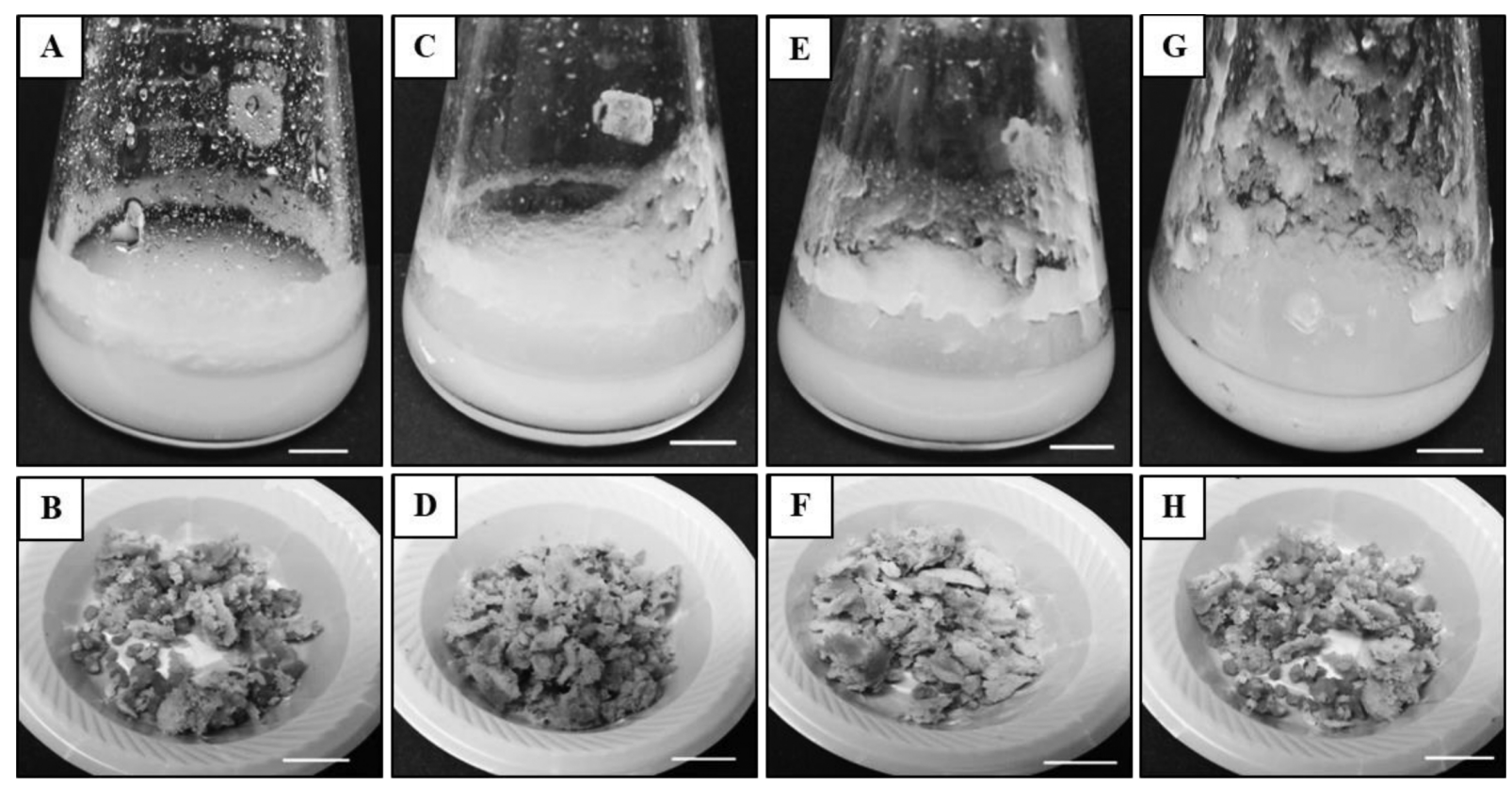

Fig. 3. The effect of subculture frequency on the morphology of cell suspension culture of $C$. nutans (upper) and dried cells (bottom). (A, B) third subculture cycle, (C, D) fifth subculture cycle, (E, F) seventh subculture cycle, and (G, H) ninth subculture cycle. Scale bars represent $1 \mathrm{~cm}$.

consisted of fine cells whereas the compact cell lines were found to produce inconsistent outcomes and were made up of big cell aggregates. A similar observation was also reported by Narayani et al. (2017) where friable callus was observed to segregate into free cells easily compared to compact callus in cell suspension cultures of Viola odorata.

In the present study, subculture frequency was observed to enhance the growth of the cells. The growth of $C$. nutans cells gradually increased and 
achieved maximum growth at the fifth subculture cycle. The decline in cell growth after the fifth subculture cycle could be due to residual effects of plant growth regulators and by-product accumulation in cultures. However, no visible morphological variation or changes were observed in the cultures. The growth of cultures became relatively stable in terms of biomass production after the eighth subculture cycle. This indicated that the cell suspension culture of $C$. nutans was successfully maintained for 10 subculture cycles. The cells were able to grow and proliferated for more than five months of culture with regular subculturing. Similarly, Lo et al. (2012) successfully maintained the cell suspension culture of Artemisia annua by subculturing the cells at 16 days intervals for 33 subculture cycles.

In this study, the cells were sieved with a sterilized stainless-steel sieve to separate small cell clumps from the larger clumps. The larger clumps were broken into small aggregates using a spatula. After a few subcultures, the cells appeared to be homogenous which consisted of small aggregates and fine cells. Liu et al. (2018) also observed that the cell suspension of Gardenia jasminoides showed a stable growth with a small granular texture after ten subcultures. Based on the report of Soomoro and Memon (2007), the subculture step is required to maintain consistent growth and homogenous morphology in the cell cultures. This is because cells in cultures tend to form clusters and aggregates which can affect the oxygen and nutrient absorption of the cells. Homogeneous cell cultures facilitate the uniform access of nutrition to all the cells that enhance cell growth (Narayani et al., 2017).

\section{CONCLUSION}

In conclusion, light illumination and repetitive subculture were found to significantly affect the growth of cell suspension culture of $C$. nutans. Light illumination was observed to positively impact the growth of cell cultures and the proliferation of cell mass peaked at the $5^{\text {th }}$ sub-culture cycle. The outcomes from the current study indicated that these optimized conditions could further assist the in vitro optimization of cell suspension cultures for $C$. nutans for the production of valuable secondary metabolites.

\section{ACKNOWLEDGEMENT}

This research was funded by The Ministry of Higher Education Malaysia under the Fundamental Research Grant Scheme (Grant code: 203/PBIOLOGI/6711521). We would like to thank the School of Biological
Sciences, Universiti Sains Malaysia (USM), and Agricultural Crop Trust (Malaysia) for their support.

\section{REFERENCES}

Ali, M. \& Abbasi, B.H. 2014. Light-induced fluctuations in biomass accumulation, secondary metabolites production and antioxidant activity in cell suspension cultures of Artemisia absinthium L. Journal of Photochemistry and Photobiology B: Biology, 140: 223-227.

Arullappan, S., Rajamanickam, P., Thevar, N. \& Kodimani, C.C. 2014. In vitro screening of cytotoxic, antimicrobial and antioxidant activities of Clinacanthus nutans (Acanthaceae) leaf extracts. Tropical Journal of Pharmaceutical Research, 13(9): 1455-1461.

Beigmohammadi, M., Movafeghi, A., Sharafi, A., Jafari, S. \& Danafar, H. 2019. Cell suspension culture of Plumbago europaea L. towards production of plumbagin. Iranian Journal of Biotechnology, 17(2): 46-54.

Bong, F.J., Chear, N.J.Y., Ramanathan, S., MohanaKumaran, N., Subramaniam, S. \& Chew, B.L. 2021. The development of callus and cell suspension cultures of Sabah Snake Grass (Clinacanthus nutans) for the production of flavonoids and phenolics. Biocatalysis and Agricultural Biotechnology, 33: 101977.

Bordbar, L., Subramaniam, S., Jelodar, N.B. \& Chan, L.K. 2015. Effects of abiotic factors on cell biomass and rosmarinic acid production in cell suspension cultures of Orthosiphon stamineus benth. Emirates Journal of Food and Agriculture, 27(10): 756-762.

Cardoso, J.C., de Oliveira, M.E.B. \& Cardoso, F.C.I. 2019. Advances and challenges on the in vitro production of secondary metabolites from medicinal plants. Horticultura Brasileira, 37(2): 124-132.

Ch'ng, S.J. \& Chan, L.K. 2013. Factors affecting the selection of callus cell lines and the preparation of the cell suspension culture of Artemisia annua L. Plant Tissue Culture and Biotechnology, 23(2): 157-163.

Dhanoa, A., Yong, T.L., Yeap, S.J.L., Lee, I.S.Z. \& Singh, V.A. 2014. Complementary and alternative medicine use amongst Malaysian orthopaedic oncology patients. BMC Complementary and Alternative Medicine, 14: 404.

Fong, S.Y., Wimalasiri, D., Piva, T., Dekiwadia, C., Urban, S. \& Huynh, T. 2019. Evaluation of cytotoxic and apoptotic activities of Clinacanthus nutans (Burm. f.) Lindau leaves against D24 human melanoma cells. Journal of Herbal Medicine, 17-18: 100285. 
Garcia, R., Pacheco, G., Falcão, E., Borges, G. \& Mansur, E. 2011. Influence of type of explant, plant growth regulators, salt composition of basal medium, and light on callogenesis and regeneration in Passiflora suberosa L. (Passifloraceae). Plant Cell, Tissue and Organ Culture, 106: 47-54.

George, E.F. 2008. Plant tissue culture: background. In: Plant propagation by tissue culture. E.F. George, M.A. Hall \& G.D. Klerk (Eds.). Springer, Netherlands. pp. 1-28.

Georgieva, L., Ivanov, I., Marchev, A., Aneva, I., Denev, P., Georgiev, V. \& Pavlov, A. 2015. Protopine production by fumaria cell suspension cultures: effect of light. Applied Biochemistry and Biotechnology, 176: 287-300.

Halliday, K.J., Martínez-García, J.F. \& Josse, E. 2009. Integration of light and auxin signaling. Cold Spring Harbor Perspectives in Biology, 1(6): a001586.

Hamid, H.A. \& Yahaya, I.H. 2016. Cytotoxicity of Clinacanthus nutans extracts on human hepatoma (HepG2) cell line. International Journal of Pharmacy and Pharmaceutical Sciences, 8(10): 293-295.

Hao, H., Lei, C., Dong, Q., Shen, Y., Chi, J., Ye, H. \& Wang, H. 2014. Effects of exogenous methyl jasmonate on the biosynthesis of shikonin derivatives in callus tissues of Arnebia euchroma. Applied Biochemistry and Biotechnology, 173(8): 2198-2210.

Hasanloo, T., Khavari-Nejad, R.A., Majidi, E. \& Shams Ardakani, M.R. 2008. Flavonolignan production in cell suspension culture of Silybum marianum. Pharmaceutical Biology, 46(12): 876-882.

Jalil, M., Annuar, M.S.M., Tan, B.C. \& Khalid, N. 2015. Effects of selected physicochemical parameters on zerumbone production of Zingiber zerumbet Smith cell suspension culture. Evidence-Based Complementary and Alternative Medicine, 2015: 757514.

Khoo, L.W., Mediani, A., Zolkeflee, N.K.Z., Leong, S.W., Ismail, I.S., Khatib, A., Shaari, K. \& Abas, F. 2015. Phytochemical diversity of Clinacanthus nutans extracts and their bioactivity correlations elucidated by NMR based metabolomics. Phytochemistry Letters, 14: 123-133.

Kong, H.S. \& Abdullah Sani, N. 2017. Nutritional values and amino acid profiles of Clinacanthus nutans (Belalai Gajah/Sabah Snake Grass) from two farms in Negeri Sembilan, Malaysia. Pertanika Journal of Tropical Agricultural Science, 40(4): 639-652.
Kong, H.S., Musa, K.H., Mohd Kasim, Z. \& Abdullah Sani, N. 2019. Qualitative and quantitative phytochemical analysis and antioxidant properties of leaves and stems of Clinacanthus nutans (Burm. f.) Lindau from two herbal farms of Negeri Sembilan, Malaysia. ASM Science Journal, 12: 1-13.

Kunsorn, P., Ruangrungsi, N., Lipipun, V., Khanboon, A. \& Rungsihirunrat, K. 2013. The identities and anti-herpes simplex virus activity of Clinacanthus nutans and Clinacanthus siamensis. Asian Pacific Journal of Tropical Biomedicine, 3(4): 284-290.

Liu, Z.B., Chen, J.G., Yin, Z.P., Shangguan, X.C., Peng, D.Y., Lu, T. \& Lin, P. 2018. Methyl jasmonate and salicylic acid elicitation increase content and yield of chlorogenic acid and its derivatives in Gardenia jasminoides cell suspension cultures. Plant Cell, Tissue and Organ Culture, 134(1): 79-93.

Lo, K.Y., Jelodar, N.B. \& Chan, L.K. 2012. Investigation on the effect of subculture frequency and inoculum size on the artemisinin content in a cell suspension culture of Artemisia annua L. Australian Journal of Crop Science, 6(5): 801-807.

Mai, C.W., Yap, K.S., Kho, M.T., Ismail, N.H., Yusoff, K., Shaari, K., Chin, S.Y. \& Lim, E.S. 2016. Mechanisms underlying the anti-Inflammatory effects of Clinacanthus nutans Lindau extracts: inhibition of cytokine production and toll-like receptor-4 activation. Frontiers in Pharmacology, 7: 7.

Mir, M.Y., Kamili, A.N., Hassan, Q.P. \& Tyub, S. 2017. Effect of light and dark conditions on biomass accumulation and secondary metabolite production in suspension cultures of Artemisia amygdalina Decne. Journal of Himalayan Ecology and Sustainable Development, 12: 107112.

Murashige, T. \& Skoog, F. 1962. A revised medium for rapid growth and bioassays with tobacco tissue cultures. Physiologia Plantarum, 15(3): 473-497.

Murthy, H.N., Lee, E. \& Paek, K. 2014. Production of secondary metabolites from cell and organ cultures: strategies and approaches for biomass improvement and metabolite accumulation. Plant Cell, Tissue and Organ Culture, 118: 1-16.

Mustapa, A.N., Martin, A., Mato, R.B. \& Cocero, M.J. 2015. Extraction of phytocompounds from the medicinal plant Clinacanthus nutans Lindau by microwave-assisted extraction and supercritical carbon dioxide extraction. Industrial Crops and Products, 74: 83-94. 
Narayani, M., Chadha, A. \& Srivastava, S. 2017. Callus and cell suspension culture of Viola odorata as in vitro production platforms of known and novel cyclotides. Plant Cell, Tissue and Organ Culture, 130(2): 289-299.

Neumann, K.H., Imani, J. \& Kumar, A. 2009. Plant Cell and Tissue Culture - A Tool in Biotechnology, Principles and Practice. Springer, Berlin.

Ng, C.T., Fong, L.Y., Tan, J.J., Rajab, N.F., Abas, F., Shaari, K., Chan, K.M., Juliana, F. \& Yong, Y.K. 2018. Water extract of Clinacanthus nutans leaves exhibits in vitro, ex vivo and in vivo antiangiogenic activities in endothelial cell via suppression of cell proliferation. BMC Complementary and Alternative Medicine, 18: 210.

Phua, Q.Y., Subramaniam, S., Lim, V. \& Chew, B.L. 2018. The establishment of cell suspension culture of Sabah snake grass (Clinacanthus nutans (Burm. f.) Lindau). In vitro Cellular \& Developmental Biology - Plant, 54(4): 413-422.

Pi, Y., Jiang, K., Hou, R., Gong, Y., Lin, J., Sun, X. \& Tang, K. 2010. Examination of camptothecin and 10-hydroxycamptothecin in Camptotheca acuminata plant and cell culture, and the affected yields under several cell culture treatments. Biocell, 34(3): 139-143.

Rahim, M.H.A., Zakaria, Z.A., Sani, M.H.M., Omar, M.H., Yakob, Y., Cheema, M.S., Ching, S.M., Ahmad, Z. \& Kadir, A.A. 2016. Methanolic extract of Clinacanthus nutans exerts antinociceptive activity via the opioid/nitric oxidemediated, but cGMP-independent, pathways. Evidence-Based Complementary and Alternative Medicine, 2016: 1494981.

Raya, K.B., Ahmad, S.H., Farhana, S.F., Mohammad, M., Tajidin, N.E. \& Parvez, A. 2015. Changes in phytochemical contents in different parts of Clinacanthus nutans (Burm. f.) Lindau due to storage duration. Bragantia, 74(4): 445-452.

Rikiishi, K., Matsuura, T., Maekawa, M. \& Takeda, K. 2008. Light control of shoot regeneration in callus cultures derived from barley (Hordeum vulgare L.) immature embryos. Breeding Science, 58: $129-135$.

Sarega, N., Imam, M.U., Ooi, D.J., Chan, K.W., Md Esa, N., Zawawi, N. \& Ismail, M. 2016. Phenolic rich extract from Clinacanthus nutans attenuates hyperlipidemia-associated oxidative stress in rats. Oxidative Medicine and Cellular Longevity, 2016: 4137908.
Soomro, R. \& Memon, R.A. 2007. Establishment of callus and suspension culture in Jatropha curcas. Pakistan Journal of Botany, 39(7): 24312441.

Tabata, H. 2004. Paclitaxel production by plant-cellculture technology. Advances in Biochemical Engineering/Biotechnology, 87: 1-23.

Tan, S.H., Musa, R., Ariff, A. \& Maziah, M. 2010. Effect of plant growth regulators on callus, cell suspension and cell line selection for flavonoid production from Pegaga (Centella asiatica L. urban). American Journal of Biochemistry and Biotechnology, 6(4): 284-299.

Wahyuni, D.K., Huda, A., Faizah, S., Purnobasuki, H. \& Wardojo, B.P.E. 2020. Effects of light, sucrose concentration and repetitive subculture on callus growth and medically important production in Justicia gendarussa Burm. f. Biotechnology Reports, 27: e00473.

Wang, K.S., Chan, C.K., Hidayat, A.F.A., Wong, Y.H. \& Kadir, H.A. 2019. Clinacanthus nutans induced reactive oxygen species-dependent apoptosis and autophagy in HCT116 human colorectal cancer cells. Pharmacognosy Magazine, 15(60): 87-97.

Wu, C.H., Murthy, H.N., Hahn, E.J. \& Paek, K.Y. 2007. Enhanced production of caftaric acid, chlorogenic acid and cichoric acid in suspension cultures of Echinacea purpurea by the manipulation of incubation temperature and photoperiod. Biochemical Engineering Journal, 36(3): 301-303.

Yong, Y.K., Tan, J.J., Teh, S.S., Mah, S.H., Ee, G.C.L., Chiong, H.S. \& Ahmad, Z. 2013. Clinacanthus nutans extracts are antioxidant with antiproliferative effect on cultured human cancer cell lines. Evidence-based Complementary and Alternative Medicine, 2013: 462751.

Yue, W., Ming, Q.L., Lin, B., Rahman, K., Zheng, C.J., Han, T. \& Qin, L.P. 2016. Medicinal plant cell suspension cultures: pharmaceutical applications and high-yielding strategies for the desired secondary metabolites. Critical Reviews in Biotechnology, 36(2): 215-232.

Zhang, Y.H., Lu, Y.Y., He, C.Y. \& Gao, S.F. 2019. A method for cell suspension culture and plant regeneration of Angelica sinensis (Oliv.) Diels. Plant Cell, Tissue and Organ Culture, 136: 313322. 